\title{
Creative Accounting-Nature, Usage, Labor and Relation with the Own Crisis Consequences in Practice in Kosovo
}

\author{
PhD Cand. Arbana Sahiti \\ University of Pristina, Faculty ofEconomy in Pristina, 10000 Kosovo \\ Prof. dr. MuhametAliu \\ University of Pristina, Faculty of Economy in Pristina, 10000 Kosovo
}

\begin{abstract}
This project aims to provide a detailed view of the actual implementation of C reative Accounting (CA) concept amongst professionals in Pristina city. To accomplish this project I have tried to cover the below various topics: -Definitions of $(C A)$; Motivation behind (CA); The various ways and methods in which (CA) can be assumed; Why management decides to involve in (CA); The roles of Governance, Regulators and Auditors; Ethical issues resulting from practicing $(C A)$, and the difference between $(C A)$ and fraud. 20 financial executives were surveyed, to determine the key factors on how they interacted with the (CA) concept and its implementation. 10 of these were semi-structured interviews. At the end, it was concluded that the complex and diverse nature of the business transactions and the autonomy existing in accounting standards and policies make it difficult to manage the issue of $(\mathrm{CA})$. This does not mean that $(\mathrm{CA})$ results are always incorrect. It is rather the determination, scale, materiality and timing of the disclosure which determine its true nature and justification.
\end{abstract}

Keywords: Creative Accounting, Earning Management, Income Smoothing, Accounts Manipulations, Big Bath Accounting,

JEL: F0,Go,G2,G3

\section{Introduction}

Accounting and its own purpose: Accounting is concerned with collecting, analyzing and communicating financial information (Atrill, Mclaney, 2008). The same will be useful for all stakeholders who need to take decisions and plan accordingly, including managers and staff who work for the same firm. The information provided by accountants should be sufficient to support decision making in terms of investment in buying or selling shares, purchasing goods, securing facilities from banks, etc.

Accounting classified into two categories; financial accounting which is concerned with preparing financial reports that provides information about a firm's performance to serve the needs of external parties such as investors, creditors and tax authorities. The second category is managerial accounting which is bonds with financial accounting in that managerial accounting is for internal decision making.

So accountants in general help companies to operate more efficiently, maintain financial records accurate and up-to-date and ensure taxes are paid on time. They execute other duties, such as analyze financial data, complete tax forms, prepare financial reports, and any other compliance task companies might require.

Accounting and Financing: Although both help in decision making, financing is concerned more with cash and how funding will be raised and where it will be invested.

It is vital to identify the users of (CA), prior to jumping to it; and who the users of accounting information are.

Figures 1. 1: Users of accounting information: 


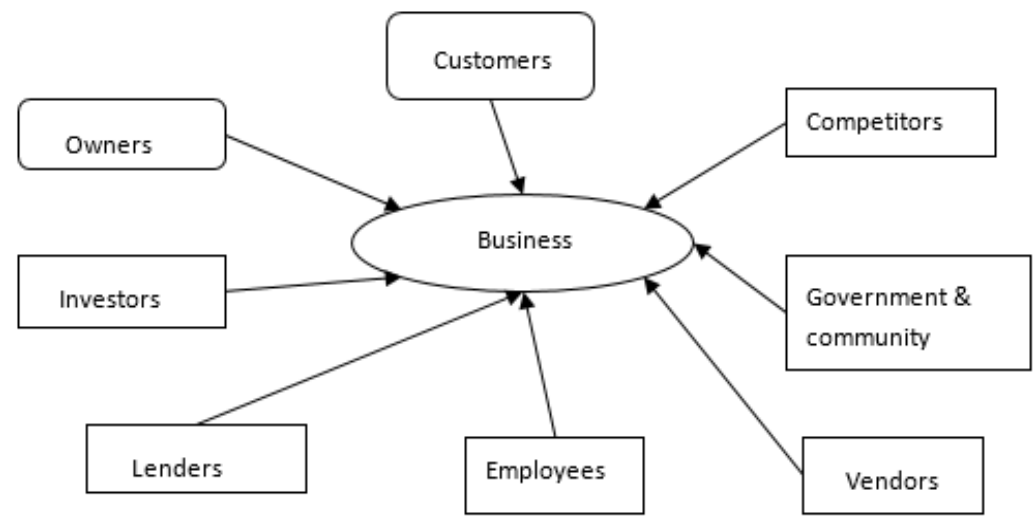

Source: (Herve Stolowy, Gary Breton, 2003)

To comply with the expectations of the above users, the size of information should be reliable, relevant, comparable and understandable. Accountants need to have proper judgments of the materiality of figures, and appropriate evaluation of cost and benefit before publishing any financial information. In other words, all information produced by accountants should be relevant to the concerned reader, comparable with the same information of last year, and easy to understand. Accountants should not ignore any amount crossing the threshold of materiality and lastly it should balance the cost and benefit of displaying of such information.

Over the last two to three decades, accounting has become more interesting, especially after the disreputable cases of companies collapsing due to books manipulation; Enron and WorldCom are best examples of such companies where misrepresentation and playing with published figures has jeopardized the credibility and honesty of these companies' management and led to total collapse. Warren Buffett believed that the accounting scandals were committed during (the new economy boom) of the late 1990s, when confidence was high and exaggerated predictions were being made concerning the future (The Times, 2002). (Barry Cooper, Robert Grose, 2010) argued that the failures of WorldCom, Enron in the US, and Bond Corporation and HH Insurance in Australia were not technical. They said "The Creative Accounting accepted by Arthur Andersen at WorldCom is what students would study in Accounting 101; at Enron, with its special purpose entities, it was Accounting 102. Arguably, the failure of Arthur Andersen audits was not a technical, but rather an ethical failure".

According to Stolowy and Breton (2004) there were a lot of players in the accounts manipulation game as we will see in the next scheme: (Source: Stolowy and Breton (2004))
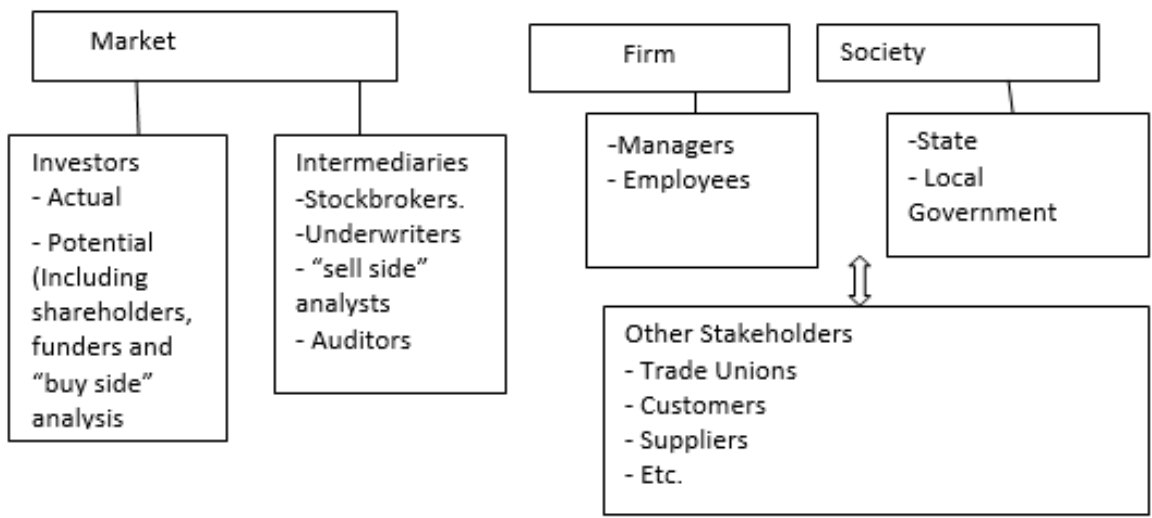
Changes facing Accounting (Peter A, Eddie M, 2008):

- The increasing sophistication of customers.

- The development of a global economy where national frontiers become less important.

- Rapid changes in technology.

- The deregulation of domestic markets (For example, electricity, water, gas).

- Increased pressure from owners (shareholders) for competitive economic returns.

- The increasing volatility of financial markets.

\begin{tabular}{|c|c|c|}
\hline Players & Gains & Losses \\
\hline Managers & $\begin{array}{l}\text { Reducing the cost of capital. } \\
\text { Keeping their job. } \\
\text { Managing their remunerations. } \\
\text { Respecting the debts covenants. } \\
\text { Official ex amination. } \\
\text { Minimizing income tax. } \\
\text { Gaining tax adv antages. } \\
\text { Improving relations with creditors, employees and } \\
\text { inv estors. } \\
\text { Av oiding political costs. }\end{array}$ & The job and reputation. \\
\hline Existing shareholders & $\begin{array}{l}\text { Increasing market value of their shares. } \\
\text { Controlling employees claims. } \\
\text { Reducing the cost of capital. } \\
\text { Reducing the v olume of transactions. }\end{array}$ & Confidence in the market. \\
\hline Ex isting bondholders & $\begin{array}{l}\text { Increasing market value of their bonds. Controlling } \\
\text { employ ees claims. }\end{array}$ & $\begin{array}{l}\text { Wealth transfer to the actual } \\
\text { shareholders. }\end{array}$ \\
\hline Employ ees & $\begin{array}{l}\text { Keeping their jobs. } \\
\text { Increasing the remunerations. }\end{array}$ & $\begin{array}{l}\text { Their jobs in case of unex pected } \\
\text { bankruptcy. }\end{array}$ \\
\hline Suppliers & Keeping their clients. & $\begin{array}{l}\text { Some money following an unexpected } \\
\text { bankruptcy. }\end{array}$ \\
\hline Clients & $\begin{array}{l}\text { Ensuring serv ices continuity. } \\
\text { Improving warranty respect by suppliers. }\end{array}$ & $\begin{array}{l}\text { Serv ices interrupted Warranties not } \\
\text { honoured }\end{array}$ \\
\hline State & $\begin{array}{l}\text { Collecting Tax. } \\
\text { Securing Jobs for people. }\end{array}$ & $\begin{array}{l}\text { No more tax to collect. } \\
\text { More unemployed people to provide for. }\end{array}$ \\
\hline Bankers & Repay ment of the loans. & $\begin{array}{l}\text { Some money following an unexpected } \\
\text { bankruptcy. }\end{array}$ \\
\hline Society & Keeping their jobs. Production of w ealth. & Jobs lost and resources wasted. \\
\hline
\end{tabular}

Source: Stolowy and Breton (2004)

The conflict of interest among different interest groups is the real cause of (CA) (Diana, B., Victoria, B. and Alina, V 2009), and this type of (CA) has led (David Schiff,1993) to warn investors; in general that taking a company's financial statement at face value can be a recipe for disaster. (David Schiff, 1993) has mentioned six of the many ways companies can change their earnings:

- Hiding pension liabilities.

- Capitalizing expenses instead of writing them off.

- Receivables or inventories growing faster than sales.

- Negative cash flow.

- Consolidating owned subsidiary's income and net worth, with the impossibility of receiving the same.

- Following seemingly conservative practice in a situation of reverse direction [e. g., if layers of lower priced LIFO (last-in, first-out) - cost inventory are "inflated" and sold at current prices, current earnings power is overstated. 


\section{LITERATURE REVIEW}

\section{1. Definition of Creative Accounting.}

Involves the repetitive selection of accounting measurement or reporting rules in a particular pattern, the effect of which is to report a stream of income with a smaller variation from trend than would otherwise have appeared"(Copeland, 1968). "Is the deliberate dampening of fluctuations about some level of earnings considered to be normal for the firm" (Barnea et al. 1976)

Definition from the assessment of a business journalist: "Every company in the country is fiddling its profits. Every set of accounts is based on books which have been gently cooked or completely roasted. The figures which are fed twice a year to the investing public have been changed in order to protect the guilty. It is the biggest con trick since the Trojan horse".

Any accountant worth his salt will confirm that this is no wild assertion. There is no argument over the extent and existence of this corporate contortionism, the only dispute might be over the way in which it is described. Such phrases as 'cooking the books', 'fiddling the accounts', and 'corporate con trick' may raise eyebrows where they cause people to infer that there is something illegal about this pastime. In fact, this deception is all in perfectly good taste. It is totally legitimate - it is Creative Accounting. (lan Griffiths, 1986)

Definition from the assessment of accounting perspective: "The accounting process consists of dealing with many matters of judgment and of resolving conflicts between competing approaches to the presentation of the results of financial events and transactions... this flexibility provides opportunities for manipulation, deceit and misrepresentation. These activities practiced by the less scrupulous elements of the accounting profession - have come to be known as 'C reative Accounting" (Michael Jameson, 1988).

Definition from an investment point of view: "We felt that much of the apparent growth in profits which had occurred in the 1980s was the result of accounting sleight of band rather than genuine economic growth, and we set out to expose the main techniques involved, and to give live examples of companies using those techniques" (Terry Smith, 1992).

Academic definition: "Purposeful intervention in the external financial reporting process with the intent of obtaining some exclusive gain, Creative Accounting is the transformation of financial accounting figures from what they actually are to what preparer desires by taking advantage of the existing rules and/or ignoring some or all of them"(Kamal Naser, 1993).

\section{2. Motivation behind (CA)}

According to (Healy and Whalen1999), the major motivations behind engaging in (earning management) include: - Public offerings, Regulation., Executive compensation., Financial liabilities.

Meanwhile (Schipper, 1989) provides a conceptual framework for analyzing earnings management from an informational perspective. (Beneish, 2001) added insider trading to this list of motives; managers aware of misstatement of profits can benefit by trading in the securities.

Three broad objectives for (earnings management) were suggested by (Stolowy and Breton, 2000):

- Minimization of political costs.

- Minimization of the cost of capital.

- Maximization of managers' wealth.

(Deangelo, 1988) refers to earnings management in buyout cases. (Teoh, Welch and Wong, 1998) found that firms manage earnings prior to seasoned equity offers and IPO's.

(Burgstahler and Eames, 1998) conclude that firms manage earnings to meet financial analysts' forecasts.

According to (Syed Zulfiqar Ali Shah1, Safdar Butt, 2011) Managers are motivated towards (CA) for the following reasons:

- To meet internal targets.

- To meet external expectations. 
- As window dressing for an IPO or a loan.

- Change in management.

- To provide income smoothing. Also (Beidleman, 1973) observes the positive effects of such income smoothing on expectations.

- Taxation. (Hepworth,1953) identified also several motivations including the existence of tax levies based on income, confidence by shareholders and workers in management that is able to report stable earnings and psychological expectations relating to increases or decreases in anticipated income. Tax is mentioned as a significant motivator also by (Niskanen and Keloharju, 2000) in a Finnish context and in Japan by (Herrmann and Inoue, 1996).

Other motivations for (CA) discussed by (Healy and Wahlen, 1999) include those provided when significant capital market transactions are anticipated, and when there is a gap between the actual performance of the firm and analysts' expectations.

\section{3. Various methods of (CA).}

(Oriol Amat, John Blake and Jack Dowds, 1999) identified the various methods of (CA) as follows:

- Sometimes the accounting rule allows a company to choose between different accounting methods.

- Certain entries in the accounts involve an unavoidable degree of estimation, judgment, and prediction.

- Artificial transactions can be entered into both to manipulate balance sheet amounts and to move profits between accounting periods.

- Genuine transactions can also be timed so as to give the desired impression in the accounts.

Short selling of assets was an innovative way of manipulation (The basic principle followed is selling something high now, to buy lower later, to recognize profit). This practice, which started late in 1609 by the Dutch merchant Isaac Le Maire, was widely used and is considered one of the reasons that influenced the recession and caused the crisis in 2007. The same was banned and restricted by almost all European countries and USA starting from 2008.

More pressure on $(\mathrm{CA})$ is noticed in large companies as a result of rumor spreading. The same can be seen in stock markets and derivatives and commodity markets.

\section{4. Examples from the world and the financial crisis.}

(Mary Low, Howard Davey and Keith Hooper, 2008) illustrate the role that accountants have played in these "achievements":

- Enron: Accounting/off balance sheet contrivances; Chief Financial Officer indicted; company bankrupt; billions of equity value lost.

- Tyco: Chief Executive Officer charged with tax evasion, waste of corporate assets; massivecharge of $\$ 6$ billion to earnings after disposal of CIT unit.

- WorldCom: \$3. 8 billion fraud; loans to Chief Executive Officer; bankruptcy.

- Adelphia Communications: Off balance sheet loans to senior officers.

- Xerox: Accountant overstates profits by $\$ 1.4$ billion.

- Global Crossing: Filed for bankruptcy after fiddling accounts.

- Qwest Communications: Chief Executive Officer resigned; profits restated, assets cut by $50 \%$, or $\$ 34$ billion; share price dropped.

- Health South: \$1. 4 billion fraud; false entries created in income statements and balance sheets. 
- $\$ 110$ billion merger of AOL and Time Warner cemented with inflated accounting of AOL revenues; within 18 months, the company value declined by $75 \%$, and massive write-downs of asset values were taken - AOL's 2002 earnings were written down by $\$ 98.7$ billion (a figure only slightly smaller than the European Union's budget for 2003); civil litigation ensued for damages to investors.

- Bristol-Myers: Restates $\$ 2.5$ billion in sales and $\$ 900$ million in profits after inflating distributor's stock levels; settles antitrust lawsuits for a cost of $\$ 670$ million.

- Vivendi-Universal in France: Failure of strategy; loss to shareholders; class action suits filed alleging misrepresentation of company's financial realities.

- Ahold in The Netherlands: Chief Executive Officer fired and stock price collapsed after American subsidiary was found to have falsely reported earnings.

- HIH insurance group in Australia: Failed with debts of $\$ 3.1$ billion after consistently understating claims liabilities; Chief Executive Officer, among other things, spent $\$ 340,000$ on gold watches in 1 year; criminal and civil charges pending against several directors.

- SK Global in South Korea: Overstates 2001 earnings by $\$ 1.2$ billion.

The recent financial crisis forced the United States to support banks and financial institutions from failure, USA and the western countries used financial instruments which created an abundance of credit and encouraged excessive risk-taking (Ferguson, 2008).

\section{5. Roles of Governance, regulators and Auditors.}

Woods et al (2009) observed that the role of auditors during the global recession crisis did not attract the same amount of media coverage given to the banking institutions and the regulators who appeared to be getting most of the blame.

Auditors facing changing challenges through complex financial instruments such as derivatives, credit default swaps corporate structure and ineffective regulatory mechanisms which must share some of the blame (Prem Sikka, 2009).

Derivatives were central to the collapse of financial and non-financial businesses such as Barings, Enron, and Parmalat (Prem Sikka, 2009).

The audit expectation gap is arguably one of the major issues that have been confronting the auditing profession for a number of years. (Leung et al 2009) observed ".... financial statement users such as investors, expect auditors to provide assurance concerning material fraud, irregularities and the viability of the business and its management. When entities fail through fraud or mismanagement, there is a tendency to blame the auditor for not having given adequate warning of the problems. "

Efforts to reduce the expectation gap through changes to the wording of the auditor's report, including the suggestion of a plain English version, appear to remain unfulfilled (Leung et al, 2009).

On the same subject (Houghton et al, 2009) observed, "..... it is not possible that this gap can be bridged due to a number of reasons, including the perceived complexity of financial reports, which is a function of the accounting standards and for which auditors cannot be held responsible. The wide disparity between retail and more sophisticated investors, in terms of their understanding of financial and related reports, is another reason for our view that the audit expectations gap is not closable".

It is vital to value that an auditor gives an opinion on a set of financial statements at balance date and that many of the events that led to the collapse of companies such as Lehman Brothers and the Royal Bank of Scotland, happened very quickly between reporting periods, (Woods et al, 2009).

\section{6- Towards how we can minimize, analyze and better understand (CA):}

The parties who are associated with the accounts of a company, either directly or indirectly, like - accountants, management, investors, banks, financial institutions, stock exchanges, SEBI, etc. can offer a reasonable level of confidence 
about the fidelity and fairness of accounts and efficiency of operation that calls for Credible Accounting for which the following analysis is important (Subhajit Ghosh, 2010):

- Debtors and Inventory.

- Sales vs. Debtors.

- Growth of Sales vs. Earnings.

- Return on Capital Employed (ROCE).

- Cash Flow Statement.

- Capitalization of Expenses.

- Matching Concept.

- Impact of Contingent Liability:

- True and Fair.

\section{7. Ethical Perspective \& Difference between (CA) and Fraud:}

Fraud is defined as "the intentional, deliberate, misstatement or omission of material facts, or accounting data, which is misleading and, when considered with all the information made available, would cause the reader to change or alter his or her judgment or decision" (National Association of Certified Fraud Examiners, 1993).

IFAC defines fraud as "a deliberate act committed by one or more individuals within the board, people in charge with governing the employees, or third parties, involving the use of deception to obtain an unjust or illegal advantage (IFAC 2009)".

Paul Brown (1999) narrows it as forgery, alteration or destruction of documents, registration of false operations or concealing important information.

The wider US definition sees (CA) as including fraud whereas the UK definition sees (CA) as using the flexibility within the regulatory system, but excludes fraud.

$(C A)$ is thus seen as working within the regulatory system. Hence it is not illegal. Companies using (CA) are not breaking the law, just using the flexibility in accounting to serve their own interests (Michael Jones, 2010).

Disciplinary measures have to be taken by national accounting bodies, courts, stock market, universities and colleges teaching accounting and government departments to distinguish and prevent the drawbacks of (CA).

Ethical codes need to be given more importance by the accounting professional bodies, accountants need to understand and practice ethical codes in proper manner and follow them accordingly.

\section{RESEARCH METHODOLOGY}

This study is a combination of descriptive research - structured observation- (tries to describe systematically, a situation, problem, phenomenon, service or program, or provide information about something or define attitudes towards an issue) and exploratory research - unstructured observation- (assumes to investigate an area where litte is known or to study the probability of commencing a particular research study), both styles are adopted to achieve examining the following aspect related to creative accounting $(C A)$ topics, which are considered the research objectives:

- To explore the definition of (CA).

- To find out the motivation for (CA)

- To ascertain various methods of (CA)

- To determine roles of Governance, Regulators and Auditors.

- To ascertain how we can better analyze, minimize and understand (CA) 
- To explore whether $(C A)$ is an ethical approach.

- To find out the difference between $(C A)$ and Fraud.

\section{RESULT And DISCUSSION (FINDINGS)}

The two responses with a $(\mathrm{No})$ answer on familiarity of Creative Accounting (CA) were excluded from the study so as not to influence the study negatively as their answers were more of guessing rather than proper understanding of the questions and the topic under discussion.

No consensus was reached on a definition of (CA); $53 \%$ defined it as aggressive accounting, $11 \%$ as fraudulent, $5 \%$ as crime, and $32 \%$ as other (unethical, should not be practiced, etc. ) This is mainly what I found during my search to find a unified definition. There is no agreed definition yet even in terms of content, concern, area or dimension. I found a business journalist's definition from (lan Griffiths, 1986), another from accounting perspective by (Michael Jameson, 1988), from investment point of view by (Terry Smith 1992), also from academic definition by (Kamal Naser, 1993), from management angle by (Merchant and Rockness, 1994) and from researchers point of view by (Orila Amat, john Blake and Jack Dowds, 1999) and finally from authors by (Stolowy, 2000). Other researchers such as (Michael, Jones, 2010) explained that the wider US definition sees (CA) as including fraud, whereas the UK definition sees (CA) as using the flexibility within the regulatory system, but excludes fraud; $(C A)$ is thus seen as working within the regulatory system and is not illegal. Companies using $(C A)$ are not breaking the law, but merely using the flexibility in accounting rules to serve their own interests.

The Absence of a worldwide definition of $(\mathrm{CA})$ allows companies a greater flexibility in the way they can treat various accounting issues and make decisions regarding the accounting policies they deem most appropriate to be applied. This flexibility is accepted/approved by professional accountants, who have created also a good framework in order to "speculate" the accounting legislation and to practice creative accounting (Dana, G and Diana, B 2011).

(CA) has helped more companies to get out of a crisis than land them into a crisis (Syed Zulfiqar and Safdar Butt, 2011) so if there was an agreement that $(C A)$ techniques were illegal and should not be practiced as such then companies will not find or feel that they benefit tremendously using $(C A)$ in difficult times.

$67 \%$ of the participants believed (CA) to be an old phenomenon; from my research I did not find any proper evidence documented as proof to when people started practicing (CA). Meanwhile, Warren Buffet believed that the accounting scandals were committed during the new economic boom of the late 1990s when confidence was high and inflated expectations were being made concerning the future (The Times, 2002). (Balacia Diana and Vladu Beatrice, 2009) argue that the first mention belongs to the founder of accounting - Luca Paciolo. This determination of making figures more tempting or the opposite, if the case, is as old as 500 years. In the context of brisk Venetian foreign trade, relationships between traders were recorded by double-entry bookkeeping with ink and quill-pen in main and subsidiary books. Where discrepancies arose, the inkwell was occasionally knocked over on these books - not always unintentionally - in order to make the entries illegible, hence the origin of the term "cover-up.

Accounting is a social science which has been developing with the development of the economy and market conditions. Investors, bankers, government, tax authority, employees, suppliers, customers, and others, each works for his own objectives which at times may contradict with those of the other entities. It is thus my personal belief that creative accounting has been going on with the development of accounting rules.

I further found out that $89 \%$ of the sample disagreed with the link between (CA) and recession, and only $11 \%$ believed that there is such a link between $(\mathrm{CA})$, recession and crisis, which means people believe that there are other reasons behind people engaging in $(\mathrm{CA})$.

Around $89 \%$ of the sample believed that the notes do not complement the financial statements; on the contrary, they considered the notes to be a major part of these statements and without such note, the financial figures will not have comprehensive meaning. It is fundamental to understand and asses the financial figures in a more meaningful aspect, (David Schiff, 1993) wrote to warn investors in general from taking a company's financial statement at face value as, - in his opinion- it can be a recipe for disaster. 
2/3rd of the participants did not believe that the financial standards limit or even minimize the usage of $(C A)$ and I am assuming their answer was based on the current situation where by the practice of (CA) exists and is increasing despite the existence of the standards. A report was published in The Guardian in 2008 from the US Securities Exchange Commission indicating that financial institutions collapsed or had to be saved after they received unqualified audit opinions; some examples are Lehman Brothers with an unqualified audit opinion on 28 January 2008 on its annual accounts and by early September, it filed for bankruptcy. Similarly Bear Stearns received an unqualified audit opinion on 28 January 2008, and by March its financial problems appeared. (Prem Sikka, 2009) mentioned that all these events aroused suspicion and encouraged reflection regarding the role, independence and the objectivity of the auditors.

Auditors facing changing challenges through complex financial instruments such as derivatives, credit default swaps corporate structure, and ineffective regulatory mechanisms, must share some of the blame (Prem Sikka, 2009).

Derivatives were central to the collapse of financial and non-financial businesses such as Barings, Enron, and Parmalat (Prem Sikka, 2009).

$78 \%$ of the participants considered $(C A)$ to be a curse rather than a blessing especially when we see the next question whether $(C A)$ is ethical. No one agreed that $(C A)$ can be ethical and $83 \%$ agreed it is not, meanwhile $17 \%$ did not know and zero percentage said it is considered an ethical concept. The opinion of (Barry Cooper, Robert Grose, 2010) is in harmony with this result, as they argued that the failure of WorldCom, Enron, Bond Corporation and $\mathrm{HH}$ Insurance were not technical, but rather an ethical failure. Some of the companies get the benefits of $(C A)$ but in the long run it will be a curse rather than a blessing. Many examples are listed under the section of (Examples from the world and the financial crisis) in chapter 2 by (Mary Low, Howard Davey and Keith Hopper) in their research published in 2008.

(Leung and Cooper, 1995) found that in a survey of 1500 accountants in Australia the three ethical problems cited most frequently as per following:

$\%$ of respondents

Conflict of interest 51.9

Client proposal to manipulate accounts 50.1

Client proposals for tax evasion 46. 8

The first highest percentage in my questionnaire was on (codes of ethics) question, where $94 \%$ agreed that all accountants or other professionals working in the financial sector should follow codes of ethics. Meanwhile $6 \%$ did not believe that accountants should follow any such codes,

(Hamilton, 1991) advises the following:

- To verify your suspicions about what you think is wrong.

- Search for alternative legitimate ways to achieve the desired end and offer these as an alternative approach to management. If no alternatives, report the manipulation to the appropriate authority

$83 \%$ of the participants agreed that companies derive benefits from engaging and using (CA), $11 \%$ did not believe that companies derive any such benefits from engaging and using (CA) while $6 \%$ did not answer the question. After analyzing this answer, I thought that if I would reword the question to determine if the benefits gained by companies were short or long term ones, as studies prove that there were no long term benefits identified for engaging in (CA) and all existing evidence that I was able to find was that all companies which engaged in (CA) collapsed after some time.

The highest three factors which incentivized people to engage and use (CA) were as follows, each of which scored $20 \%$ :

- Maximize earning/profit or minimize losses and/or management bonuses.

- Minimize tax liabilities.

- Boost the share price.

The other three factors which were classified as second priorities, each scoring $8 \%$, were as follows: 
- Improve financial ratio.

- Enable a failing company to obtain additional funding.

- Mislead outsiders and/ or classes of stakeholder.

Researchers and authors wrote extensively about the many ways companies can change their earning, (Schipper, 1989) provided a conceptual framework for analyzing earning management from international perspective.

(David Schiff, 1993) talked about six of these many ways such as hidden pension liabilities, capitalizing expenses, receivables or inventory growing, negative cash flow, consolidating owned subsidiary's income and net worth with the impossibility of receiving the same and lastly following seemingly conservative practice in a situation of reverse direction.

(Burgstahler and Eames, 1998) concluded that firms manage earnings to meet financial analysts' forecasts. (Healy and whalen, 1999) summarized the major motivation to be managed by:

- Public offerings.

- Regulation.

- Executive compensation.

- Financial liabilities.

They also mentioned anticipated significant capital market transactions, and the existence of a gap between the actual performance of the firm and the analyst's expectations. The same was highlighted earlier by (Beidlenman, 1973).

(Beneish, 2004) added insider trading to the list of motives as managers who are aware of misstatement of profit, can benefit by trading the securities. The commitment given by managers to shareholders or their own cities make them sensitive towards any negative changes which may lead them to misrepresent/manipulate the numbers and hope things will balance out.

Others such as (Stolowy and Breton, 2000) suggested three broad objectives for earning:

- Minimizing of political costs.

- Minimizing of cost of capital.

- Maximizing of managers' wealth.

In 2004 they wrote about potential gains and losses from manipulating accounts, (Balacia Diana and Vladu Beatrice, 2009) wrote about the conflict of interest among different interest groups which he considered the real cause of (CA).

(Syed Zulfiqar and Safdar Butt, 2011) explained managers are motivated towards (CA) for the following reasons:

- To meet internal targets.

- To meet external expectations.

- As window dressing for an IPO or loan.

- Change management.

To provide income smoothing.

- Taxation. Also (Hepworth) talked about the link between tax and (CA) in 1953 and (Herrmann and Inoue) in 1996 and (Niskanen and Keloharju) in 2000.

Many other researchers and academics wrote about motives behind (CA), (Kamin and Ronen, 1978), (Healy, 1985), (Collingwood, 1991), (Schroeder and Spiro, 1992), (Dahran and Lev, 1993), (Charles Mulford and Eugene Comiskey, 2002), (Orial Amat and Catherine Gowthope, 2002). More details of their contributions were covered under motivation of (CA) Chapter 2. 
Almost half of the participants agreed that the magnitude and or the intention were the only difference between (CA) and fraud, $39 \%$ did not believe so while $6 \%$ answered that other factors differentiate between (CA) and fraud and $6 \%$ refrained from answering the question, (Syed Shah \& Safdar Butt, 2001) indicated that it is rather the intent and the magnitude of the disclosure which determines its true nature and justification.

The measurements by which implementing will minimize the usage of $(C A)$ are listed below from highest percentage to lowest:

- Increased regulation by the stock markets, Securities and Exchange Commission and other bodies $19 \%$.

- Better education of the public, especially the younger generation (e. g. through including some basic accounting training in the National Curriculum), through enhanced learning at educational institutions $15 \%$.

- Including more explicit rules relating to Creative Accounting in the codes of conduct of the accounting profession $13 \%$.

- Introducing a statutory offence for practicing Creative Accounting so as to mislead stakeholders in the context of fraud. Consider making a presumption of guilt and require those charged to prove that they did not indulge in Creative Accounting (i. e. reverse the burden of proof) $13 \%$.

- Require the external auditor to state explicitly in his audit report the issues in respect of which, in the judgment of the external auditor, creative accounting has been used $13 \%$.

- Better education of those charged with governance, the police and the courts to equip them with the skills to investigate and prosecute "white collar" crime involving Creative Accounting $9 \%$.

- Use of forensic accountants (i. e. investigative accountants accustomed to reporting on cases of fraud involving Creative Accounting/inancial misstatement before the courts) to be made mandatory in cases where the external auditor reports positively regarding Creative Accounting $4 \%$.

- Disciplinary measures by national accounting bodies in respect of members who are involved in Creative Accounting schemes $2 \%$.

- All the above measures $13 \%$. Subhijt Gohosh, 2010) was one of researchers who wrote on how to minimize, analyze and better understand (CA) which was covered in details in chapter 2. (Sen Kumar, Inanga Eno, 2005) also wrote about forensic concept in details.

The second highest percentage of this questionnaire fell under this question as $94 \%$ agreed that merits of honesty, integrity, ownership and accountability should be stressed in accounting education to be part of accountant's DNA, while only $6 \%$ did not know the answer, (Fischer and Rosenzweing,1995) proposed two possible explanations' for accountants' attitudes:

- Accountants may take a rule-based approach to ethics, rather than considering the impact on users of the accounts.

- Accountants may see abuse of accounting rules as faulty within their domain, and therefore demanding their own ethical judgment, while the manipulation of transactions falls within the domain of management and so is not subject to the same ethical code.

(Merchant and Rockness, 1994) similarly found that, when presented with scenarios of (CA), accountants were more critical of abuse of accounting rules than of manipulation of transactions. They also found that the accountants' position towards indulging in (CA) depend on the motivation of the management.

$89 \%$ of the participants indicated that (CA) is indeed a global phenomenon, $44 \%$ of the sample did not believe it to be a regional or national phenomenon, only $33 \%$ believed it to be a national problem, $11 \%$ did not know the answer and $11 \%$ did not answer the question, (Peter A and Eddie M, 2008) explained the types of changes facing accounting in general, one of which was (the development of global economy where national frontiers become less important).

$67 \%$ did not believe that changing the terminology of "true and fair" will have any direct impact on combating (CA) and /or fraud, $22 \%$ believed it will and $11 \%$ did not know. At the same time $39 \%$ of the participants recommend a larger, wider, and or extensive role for the external auditor, $22 \%$ did not recommend any wider role and $39 \%$, which is the largest percentage, 
did not answer. Maybe this is due to the fact that a large percentage of the participants fell under other roles within the finance department and did not perform this responsibility directly so they did not know the consequences.

Although the majority wanted a wider role, only $33 \%$ from the sample believed that the market as a whole will not accept this and will not pay larger fees to external auditors to grant more additional assurance to stakeholders, $28 \%$ thought the market will accept, $11 \%$ did not know and $28 \%$ left the question unanswered.

(Leung et al, 2009) wrote about necessary efforts to reduce the expectation gap through changes to the wording of the auditor's report, while (Houghton et al, 2009) emphasized the difficulty of bridging this gap due to a number of reasons including the complexity of financial reports. Other researchers (Woods et al, 2009), (Sikka, 2009) and (Alina Vladu, Dumitru Matis, 2010). 33\% of the participants indicated that if they were asked to engage in (CA) they would refuse and report the matter to a different authority such as (Board of Directors, Audit Committee, Senior management, Statutory bodies, Stock Exchange and Accounting board), meanwhile $28 \%$ will simply refuse without taking any further action, $11 \%$ will accept and $22 \%$ might take another action depending on the situation; $6 \%$ did not answer the question.

$67 \%$ of the sample did not believe that $(C A)$ is a legitimate business tool, meanwhile $22 \%$ believed it to be a legitimate one, (Subhajit Ghosh, 2010) distinguished between fraudulent and (CA) by saying:

- Intent; the fraudulent intent to mislead the financial statements in a material way with some motive.

- (CA) may be presented as bending the rules while fraudulent accounting leads to breaking the rules.

$50 \%$ of the participants did not believe that the (CA) problem can be solved; only $33 \%$ believed it can be and $6 \%$ did not know, meanwhile $11 \%$ did not answer the question.

\section{Conclusion And Recommendation}

In my professional opinion Creative Accounting $(C A)$ is the art of using the elasticity in accounting, within the regulatory framework, to manage the production of the accounts in a way that it best represents the interests of the preparer rather than those of the user.

"A form of accounting which, while complying with all regulations, nevertheless gives a biased impression (generally fav orable) of the company's performance". The official terminology (Chartered Institute of Management Accounting, 2000).

Despite large sums of money being invested for improving and developing accounting competences over the last decades - specially in accounting practice or research - still the world experienced not one large regional / international financial crisis but seven since the 1970s (Olov olson,2011).

Close supervision and continuous collaborate efforts between:

- Professional accounting bodies: To come up with a globally acceptable definition of $(C A)$ - in terms of parameter, frequency, dimension and scope-and at the same time improving, updating and guiding participant knowledge and equipping them with the most updated knowledge towards (CA), clearing all doubts associated with the different perceptions attached with the usage of $(\mathrm{CA})$ and to sponsor along with universities a code of conduct for all their members.

- Central banks and stock markets: Integral part of continuous improvement of law to minimize and control fraud and unify the efforts across all countries' central banks to supervise fake transactions across these countries. More advanced regulations against money laundering. Full disclosure of companies around the year with better attention to yearly financial results as it contains the maximum art work of $(C A)$.

- Universities: Structure the curriculum to accommodate teaching ethics and (CSR) as an important part of study across all subjects.

- Public and private sectors: Adopt fully the (CSR) and proper segregation of duties and responsibilities and stay away from conflict of interest.

- Auditors independent: I suggest a standard fee for each audit criteria set up by the government and by this we ensure no compromise between services and fees. The negative impact of continuous pressure on reducing audit fees -as per market conditions and competition-, forced auditors to cut corners and miss more (CA) (reduce the number of qualified resources, 
squeeze the time spent for each company's audit, and stretch resources to accommodate many companies at the same time). All influenced the quality of audit negatively)

- Unify the audit thresholds between audit firms - materiality percentage- the advantage is to limit the managements scope of passing any entry outside the audit zone through changing auditors. These transaction-outside auditor interest-classified and reported normally by auditors through a report called summary of unadjusted audit difference (SOUAD), in other meaning each audit firm will have some flexibility to ignore/ not to audit certain transaction if it falls under acceptable materiality percentage, that is whether these transactions were provided by management at last minute or auditors did not agree on treatment adopted by management.

Tax authorities, government: Transparency and focus on the big picture with a revised set of updated rules and regulations which incentivize investors and will encourage management to comply and obey the rules. Proper differentiation between (CA), fraud and crime. Better control of auditors and $r$ of audit field work and proper monitoring of board of directors by enforcing legal accountability for their decisions, and establishing new laws to protect investors. Also create harmony and bonds between all parties mentioned above.

- And more specifically, we, in this region, need to adopt any initiatives, efforts, law, regulation and frame work which can help us as a society, companies or even individuals to achieve our goals towards (CA) and capitalize in the learning curve developed somewhere else rather going again into this learning curve, for example, adopting the OECD (principle of Corporate Governance which covers certain aspects of accounting and auditing in relation to corporate governance). It is a USA principle of corporate governance which is considered to be essential to the reliability and stability of financial systems and as having the key role in measures to reinforce international financial style. There are five basic subjects covered by the OECD principles of corporate governance as follows (Alina, V. and Dumitru, M.,2010):

- Protection of the rights of shareholders.

- Equitable treatment of all shareholders comprising full disclosure of material information and also the prohibition of abusive self-dealing and insider trading.

- Equitable treatment of all stakeholders as established by law and encouragement of cooperation between company and stakeholders.

- Timely and accurate disclosure and transparency with respect to matters material to company performance, ownership and governance.

- Strategic guidance of the company and effective monitoring of its management by the board of directors as well as the board's accountability to the company and its shareholders ensured by the corporate governance framework

\section{Reference}

[1] Alina, V. and Dumitru, M. (2010) Corporate Governance and Creative Accounting. Two Concepts Strongly Connected? Some Interesting Insights Highlighted by constructing the internal history of a literature, publicata în Annales Universitatis Apulensis Series Oeconomica. $\underline{N / A}$

[2] Amy, S. (1994) Debt-Covenant Violations and Managers. Accounting Responses, Journal of Accounting \& Economics. Doi: 10. 1016/0165-4101(94)90030-2

[3] Anderson, J. Richard and Tirrell, Michael E (2004) Too Good to Be True CEOs and Financial Reporting Fraud. Consulting Psychology Journal: Practice and Research . Doi: 10. 1037/1061-4087. 56. 1. 35

[4] Barrv. C. and Robert. G. (2010) Trust me: I'm An Auditor, International Review of Business Research Papers. Doi.: / 10. 21102/irbrp

[5] Carl, B. (1973) Income smoothing: The role of management. The Accounting Review. N/A

[6] Charles, M. and Eugene, C. (2002) the Financial Numbers Game. Detecting Creative Accounting Practices, New York: John Wiley \& Sons Inc. Doi: 10. 5860/choice. 39-5905 
[7] Christopher, S. and Leah, S. (1992) does everything add up at Westinghouse Credit, Business week. N/A

[8] Dana, G and Diana, B. (2011) from creative accounting practices and Enron phenomenon to the current financial crisis. $\underline{N} / \mathrm{A}$

[9] David, B. and Michael, E. (1998) Management of earning and analyst forecast, working paper, University of Washington and Santa Clara University. $\underline{\text { N/A }}$

[10] David, H. C. (1991) Why K-mart's good news isn't, Business week. N/A

[11] David, S. (1993) the Dangers of Creative Accounting, Worth. N/A

[12] Diana, B., Victoria, B. and Alina, V. (2009) a brief review of Creative Accountina literature and its consequences in practice, publicata în Annales Universitatis Apulensis Series Oeconomica. N/A

[13] Dilip, S. and Eno, I. (2005) Creative Accounting in Bangladesh and Global Perspectives, Partners' Conference Program Book, Partners' Conference, Maastricht School of Management, the Netherlands. N/A

[14] Drew, D. (1996) Managerial turnover and successor accounting discretion: bank loan loss provisions after resignation, retirement, or death', Research in Accounting Regulation. N/A

[15] Ferguson, N. (2008) the ascent of money: A financial history of the world. London: Allen Lane. N/A

[16] Ghislain, B. and Richard. T. (1995) Creative Accountina and investment analyst response, Accounting and Business Research. Doi: 10. 1080/00014788. 1995. 9729931

[17] Herve, S. and Gary, B. (2000) a framework for classification of accounts manipulation. Working Paper, HEC France and University du Quebec à Montreal.. N/A

[18] Herve, S. and Gary, B. (2004) Accounts Manipulation. A Literature Review and Proposed Conceptual Framework, Review of Accounting and Finance. Doi: 10. 1108/eb043395

[19] lan, G. (1986) Creative Accounting, London: Sidgwick and Jackson. N/A

[20] IFAC (International Federation of Accountants) (1992) IFAC Handbook 1992: Technical Pronouncements (New York: IFAC). Doi: 10. 1016/b978-0-08-041275-7. 50001-6

[21] IFAC (International Federation of Accountant), (2011), [Online], Available: http://www. ffac. org/

[22] Investopedia (2016) [Online], Available: htp://www. investopedia. com/ $\underline{\mathrm{N} / \mathrm{A}}$

[23] Joan, H. (1991) Blowing the whistle without paying the piper, Business week. N/A

[24] Kamal, N. (1993) Creative Financial Accounting. Its Nature and Use, Hemel Hempstead: Prentice Hall.

[25] Katherine, S. (1989) Commentary on Creative Accounting, Accounting Horizons.

[26] Kenneth, M. and Joanne, R. (1994) the ethics of manaaina earninas. An empirical investigation, Journal of Accounting and Public Policy. . Doi: 10. 1016/0278-4254(94)90013-2

[27] Lee, M. (1977) the Accounting Establishment. Staff studies as the Chairman of the US Senate Subcommittee, Washington, D. C: The United States Government Printing Office. N/A

[28] Linda, D. (1988) Managerial competition, information costs and corporate governance: The use of accountina performances measures in proxy contests. Journal of Accounting and Economics. Doi: /10. 1016/0165$\underline{4101(88) 90021-3}$ 
[29] MacBarnet, D., Whelan, C. (1999) Creative Accounting and the Cross-eyed Javelin Thrower, Chichester: John Wiley \& Sons Ltd. $\underline{N / A}$

[30] Margaret, W., Christopher, H., Kevin, D. and Yu-lin Liu (2009) Crunch Time for Bank Audits? Questions of Practice and the Scope for Dialogue, Managerial Auditing Journal. Doi:10. 1108/02686900910924545

[31] Marilyn, F. and Kenneth, R. (1995) Attitudes of students and accountina practitioners concerning the ethical acceptability of earnings management, Journal of Business Ethics. . Doi.: /10. 1007/bf00872085

[32] Mary, L., Howard, D. and Keith, H. (2008) Accountina scandals. ethical dilemmas and educational challenges. Critical Perspectives on Accounting. Doi: 10. 1016/j. cpa. 2006. 05. 010

[33] Messod, B. (2001) Earnings Management. A Perspective, Managerial Finance. .Doi: 0. 2139/ssm. 269625

[34] Michael, J. (2010) Creative Accounting, fraud and international scandals, England: John Wiley \& Sons. N/A

[35] Nathan, H. (2004) Corporate Ethics, Governance and Social Responsibility: Comparing European Business N/A Practices to those in the United States, A Study Conducted for the Business and Organizational Ethics Partnership Markkula Center for Applied Ethics Santa Clara University. N/A

[36] National Association of Certified Examiners (1993) Cooking the books. What every accountant should know about fraud, Self-Study Workbook. N/A

[37] Olov, O. (2011) Research about Financial crisis in the Academic accounting literature the last 4 decades. Published in leading journal $\underline{\mathrm{N} / \mathrm{A}}$

[38] Oriol, A. and Catherine, G. (2002) Creative Accountina: Nature, Incidence and Ethical Issues, Journal of Economic Literature classification. Doi:10. 2139/ssrn. 563364

[39] Oriol, A., John. B. and Jack, D. (1999) the Ethics of Creative Accounting, Journal of Economic Literature Classification. N/A

[40] Patricia, D. and Douglas, S. (2000) Earning Manadement: Reconcilina Views of Accounting Academics, Practitioners and Regulators, Accounting Horizons. Doi: 10. 2308/acch. 2000. 14. 2. 235

[41] Paul, B. (1999) Earnina management, a suitable (and troublesome) twist to earning quality, Journal of Financial statement Analysis. $\underline{\mathrm{N} / \mathrm{A}}$

[42] Paul, H. and James, W. (1999) a review of the Creative Accountina literature and its implications for standard setting, Accounting Horizons. . Doi: 10. 2308/acch. 1999. 13. 4. 365

[43] Peter, A. and Eddie. M. (2008) Accounting and Finance for Non-specialists, 6th edition, England: Pearson Education limited. $\underline{N / A}$

[44] Philomena, L. and Barry Cooper (2003) Modern Auditing and Assurance Services, 4th edition, Australia: John Wiley and Sons. N/A

[45] Robert, L. (1990) The Relation Between stock Returns and Accounting Earnings Given Alternative Information, The Accounting Review. N/A

[46] Robert. L. (2011) Mastering Your business Dissertation, 1th edition, England: Routledge. Doi. 10. $\underline{4324 / 9780203816158}$

[47] Sikka. P. (2009) financial crisis and the silence of the Auditors. Accounting, Organizations and Society. Doi.: 10. 1016/j. aos. 2009. 01.004 
[48] Subhajit, G. (2010) Creative Accounting: A fraudulent practice leading to corporate collapses Research and practice in social sciences. $\underline{N} / \mathrm{A}$

[49] Syed, S. and Safdar, B. (2001) Creative Accounting. A Tool to help companies in a crisis or a practice to land them into crisis, Singapore, IACSITPress. N/A

[50] Teoh, S., Welch, I. and Wong, T. (1998) Earninas manaaement and the long-run market performance of initial public offerings, Journal of Finance. Doi: 10. 1111/0022-1082. 00079

[51] Teoh, S., Welch, I. and Wong, T. (1998) Earninas manaqement and the underperformance of seasoned equity offering, Journal of Financial Economics. Doi:10. 1016/s0304-405x(98)00032-4

[52] The Times (2002) Business section. N/A

Result / Appendix

Which one of the following descriptions resembles your role most closely?

\begin{tabular}{|l|l|l|}
\hline Head of Finance/ Finance director & 3 & $15 \%$ \\
\hline Ex ternal Auditor & 2 & $10 \%$ \\
\hline Internal Auditor & 3 & $15 \%$ \\
\hline Other Accounting role & 6 & $30 \%$ \\
\hline Ethics/Compliance/Legal/Forensic & 4 & $20 \%$ \\
\hline Director/Management & 2 & $10 \%$ \\
\hline & 20 & $100 \%$ \\
\hline
\end{tabular}

Are you familiar with the term of (CA)?

\begin{tabular}{|l|l|l|}
\hline Yes & No & Total \\
\hline 18 & 2 & 20 \\
\hline $90 \%$ & $10 \%$ & $100 \%$ \\
\hline
\end{tabular}

How do you define (CA)?

\begin{tabular}{|l|l|l|}
\hline Aggressive Accounting & 10 & $53 \%$ \\
\hline Fraudulent & 2 & $11 \%$ \\
\hline Crime & 1 & $5 \%$ \\
\hline Other, Please specify & 6 & $32 \%$ \\
\hline
\end{tabular}

Do you think that the use of $(\mathrm{CA})$ is a modern phenomenon?

\begin{tabular}{|l|l|l|l|}
\hline Yes & No & Don't know & Total \\
\hline 6 & 12 & & 18 \\
\hline $33 \%$ & $67 \%$ & $0 \%$ & $100 \%$ \\
\hline
\end{tabular}

Do you believe that (CA)usage is always linked with recession and crisis?

\begin{tabular}{|l|l|l|l|}
\hline Yes & No & Don'tknow & Total \\
\hline 2 & 16 & & 18 \\
\hline $11 \%$ & $89 \%$ & $0 \%$ & $100 \%$ \\
\hline
\end{tabular}

-Do you consider the notes to the Audited financial statements of a business to be mandatory, fundamental and important, to fully understand the financial position of the business? 


\begin{tabular}{|l|l|l|l|}
\hline Yes & No & Don't know & Total \\
\hline 16 & 1 & 1 & 18 \\
\hline $89 \%$ & $6 \%$ & $6 \%$ & $100 \%$ \\
\hline
\end{tabular}

-Are IFRS, GAAP and other financial standards sufficiently comprehensive to minimize/limit the usage of (CA)?

\begin{tabular}{|l|l|l|l|}
\hline Yes & No & Don't know & Total \\
\hline 5 & 11 & 2 & 18 \\
\hline $28 \%$ & $61 \%$ & $11 \%$ & $100 \%$ \\
\hline
\end{tabular}

Do you believe (CA) to be a blessing or a curse to organizations and their stakeholders?

\begin{tabular}{|l|l|l|}
\hline Blessing & Curse & Total \\
\hline 4 & 14 & 18 \\
\hline $22 \%$ & $78 \%$ & $100 \%$ \\
\hline
\end{tabular}

Do you consider(CA) to be ethical?

\begin{tabular}{|l|l|l|l|}
\hline Yes & No & Don't know & Total \\
\hline & 15 & 3 & 18 \\
\hline $0 \%$ & $83 \%$ & $17 \%$ & $100 \%$ \\
\hline
\end{tabular}

-Do you believe that accountants and any other professionals working in the financial sector follow codes of ethics?

\begin{tabular}{|l|l|l|l|}
\hline Yes & No & Don't know & Total \\
\hline 17 & 1 & & 18 \\
\hline $94 \%$ & $6 \%$ & $0 \%$ & $100 \%$ \\
\hline
\end{tabular}

Do companies derive benefit from the use of (CA)?

\begin{tabular}{|l|l|l|l|l|}
\hline Yes & No & Don't know & Noanswer & Total \\
\hline 15 & 2 & & 1 & 18 \\
\hline $83 \%$ & $11 \%$ & $0 \%$ & $6 \%$ & $100 \%$ \\
\hline
\end{tabular}

If you answered (Yes), please select from the list below one or more of the most important factors which incentivize them to do so.

\begin{tabular}{|l|l|l|}
\hline Maximize earning/profit or minimize losses and/or management bonuses & 12 & $20 \%$ \\
\hline Minimize tax liabilities & 12 & $20 \%$ \\
\hline Boost the share price & 12 & $20 \%$ \\
\hline Improve financial ratio & 8 & $13 \%$ \\
\hline Enable afailing company to obtain additional funding & 8 & $13 \%$ \\
\hline Mislead outsiders and/or classes of stakeholder & 8 & $13 \%$ \\
\hline Other please specify & 0 & $0 \%$ \\
\hline & 60 & $100 \%$ \\
\hline
\end{tabular}

Are magnitude and/or the intention the only difference between(CA) \& fraud?

\begin{tabular}{|l|l|l|l|l|}
\hline Yes & No & Other & Noanswer & Total \\
\hline 9 & 7 & 1 & 1 & 18 \\
\hline $50 \%$ & $39 \%$ & $6 \%$ & $6 \%$ & $100 \%$ \\
\hline
\end{tabular}

Only 50\% agreed that magnitude and/or the intention are the only differences between (CA) and fraud. The breakdown is as follows: 
- 100\% from (internal auditors and management/ director) roles.

$-50 \%$ from (head of finance, and other accounting) roles.

- 33\% from (external auditor and forensic) roles.

If there is a need to minimize/eliminate $(C A)$, which of the measures given below would you recommend implementing?

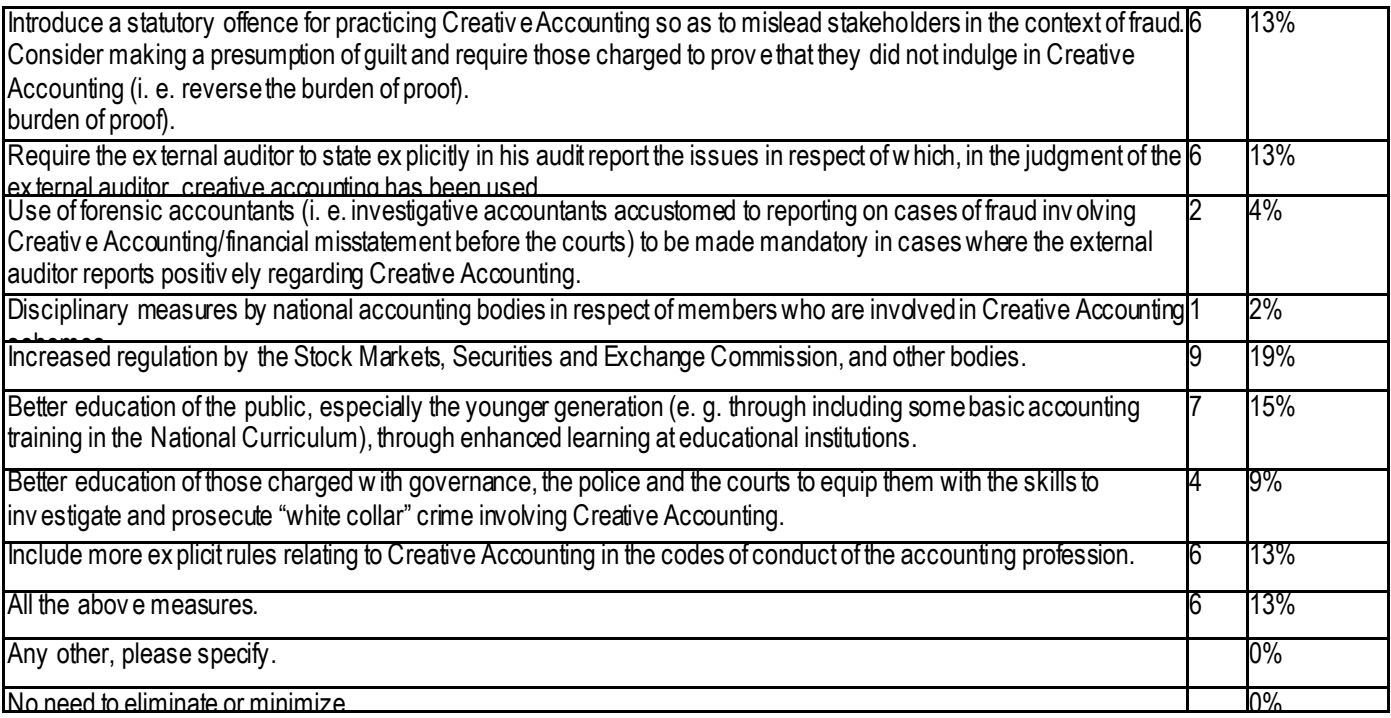

The merits of honesty, integrity, ownership and accountability should be stressed in accounting education until it becomes part of an accountant's DNA. Do you agree?

\begin{tabular}{|l|l|l|l|}
\hline Yes & No & don'tknow & Total \\
\hline 17 & & 1 & 18 \\
\hline $94 \%$ & $0 \%$ & $6 \%$ & $100 \%$ \\
\hline
\end{tabular}

- Is(CA) a global phenomenon?

\begin{tabular}{|l|l|l|l|}
\hline Yes & No & Don't know & Total \\
\hline 16 & 1 & 1 & 18 \\
\hline $89 \%$ & $6 \%$ & $6 \%$ & $100 \%$ \\
\hline
\end{tabular}

Is (CA) a regional/national phenomenon?

\begin{tabular}{|l|l|l|l|l|}
\hline Yes & No & Don't know & Noanswer & Total \\
\hline 6 & 8 & 2 & 2 & 18 \\
\hline $33 \%$ & $44 \%$ & $11 \%$ & $11 \%$ & $100 \%$ \\
\hline
\end{tabular}

Do you believe that the option available to an external auditor to modify his audit opinion on the "True and Fair" nature of an entity's financial statements is an effective way of combating (CA) and/or fraud.

\begin{tabular}{|l|l|l|l|}
\hline Yes & No & Don't know & Total \\
\hline 4 & 12 & 2 & 18 \\
\hline $22 \%$ & $67 \%$ & $11 \%$ & $100 \%$ \\
\hline
\end{tabular}

If your answer is (No), do you recommend a larger, wider, or more extensive role for the external auditor? 


\begin{tabular}{|l|l|l|l|l|}
\hline Yes & No & Don't know & No answer & Total \\
\hline 7 & 4 & & 7 & 18 \\
\hline $39 \%$ & $22 \%$ & $0 \%$ & $39 \%$ & $100 \%$ \\
\hline
\end{tabular}

- If your answer is (Yes), do you think that the market as a whole would accept this and be willing to pay a larger (external) audit fees to give stakeholders this additional assurance?

\begin{tabular}{|l|l|l|l|l|}
\hline Yes & No & Don't know & No answer & Total \\
\hline 5 & 6 & 2 & 5 & 18 \\
\hline $28 \%$ & $33 \%$ & $11 \%$ & $28 \%$ & $100 \%$ \\
\hline
\end{tabular}

If you are asked to engage in (CA), what will you do?

\begin{tabular}{|l|l|l|}
\hline Accept & 2 & $11 \%$ \\
\hline Refuse & 5 & $28 \%$ \\
\hline Refuse and report the matter(please specify to whom) & 6 & $33 \%$ \\
\hline Others, please specify & 4 & $22 \%$ \\
\hline No answer & 1 & $6 \%$ \\
\hline \multicolumn{2}{|l|}{} \\
\hline
\end{tabular}

Do you consider the use of (CA) a legitimate business tool?

\begin{tabular}{|l|l|l|l|}
\hline Yes & No & Don't know & Total \\
\hline 4 & 12 & 2 & 18 \\
\hline $22 \%$ & $67 \%$ & $11 \%$ & $100 \%$ \\
\hline
\end{tabular}

- Do you believe that $(\mathrm{CA})$ is a problem that can never be solved?

\begin{tabular}{|l|l|l|l|l|}
\hline Yes & No & Don't know & No answer & Total \\
\hline 9 & 6 & 1 & 2 & 18 \\
\hline $50 \%$ & $33 \%$ & $6 \%$ & $11 \%$ & $100 \%$ \\
\hline
\end{tabular}

